\title{
Composition of Caatinga Species Under Anthropic Disturbance and Its Correlation With Rainfall Partitioning
}

\author{
Maria Gabriela de Queiroz ${ }^{1}$ (B) \\ Thieres George Freire da Silva ${ }^{1}$ \\ Carlos André Alves de Souza ${ }^{2}$ \\ Alexandre Maniçoba da Rosa Ferraz Jardim² ${ }^{2}$ (B) \\ George do Nascimento Araújo Júnior ${ }^{2}$ (1) \\ Luciana Sandra Bastos de Souza ${ }^{1}$ \\ Magna Soelma Beserra de Moura ${ }^{3}[$ []
}

\begin{abstract}
The vegetation structure is a good indicator of the conservation condition of an ecosystem, since it reflects alterations caused by anthropic action. This study proposes to analyze the phytosociological aspects of the Caatinga domain under anthropic disturbance and their correlations with hydrological variables. Twenty-five $400 \mathrm{~m}^{2}$ plots were sampled in the municipality of Floresta - PE, Brazil. Phytosociological parameters such as density, frequency and dominance were calculated. The seasonality of plant area index was analyzed for six species. The association between structural characteristics and hydrological variables (throughfall, stemflow and interception loss) in the species was evaluated by multivariate analysis. A total of 930 individuals, six families and 10 species were recorded. The abundance of the species Cenostigma pyramidale in the area may be an indicator of the degree of change in the vegetation. The structural characteristics of the species revealed little association with rainfall partitioning.
\end{abstract}

Keywords: phytosociology, plant area index, semi-arid.

\section{INTRODUÇÃO}

The Caatinga is a domain found exclusively in the semiarid region of Brazil. Its features differentiate it from the main biomes of the world, with species highly heterogeneous and endemic, dominated by arboreal and shrubby plant species. It has thorny and herbaceous succulent plants that during dry periods lose their leaves in response to weather conditions (Beuchle et al., 2015; Queiroz et al., 2019)

The Caatinga Domain has suffered intense anthropogenic action over time (i.e., deforestation, logging and implementation of agricultural crops), and today it is estimated that half of its original surface has already been modified (Schulz et al., 2016; Vieira et al., 2013). The climatic seasonality also affect the plant cover, promoting alterations on phytosociology, and the floristic composition of the domains (Ferreira et al., 2016).

Studies of floristic and phytosociological compositions allow to know the performance of different physiognomies, to simulate future scenarios of the floristic composition, phytosociological structure, regeneration of different plant communities and of the biomass, and to subsidize forest management plans (Martins et al., 2017; Melo et al., 2019). Sampaio and Silva (2005) cited several phytosociological studies of Caatinga, generating accurate data on plant measurements in various environments.

\footnotetext{
${ }^{1}$ Universidade Federal Rural de Pernambuco (UFRPE), Serra Talhada, PE, Brasil

${ }^{2}$ Universidade Federal Rural de Pernambuco (UFRPE), Recife, PE, Brasil

${ }^{3}$ Empresa Brasileira de Pesquisa Agropecuária (EMBRAPA), Petrolina, PE, Brasil
} 
The vegetation structure can be used as an indicator of an ecosystem's conservation state. Thus, a forest inventory with multiple measurements of floristic and structural parameters is often the only way of predicting the components of vegetation changes over time (Batista et al., 2015; Rodrigues et al., 2016).

The type of vegetation in ecosystems influences the redistribution of local water resources. Therefore, interception loss is an important hydrological agent (Zhang et al., 2015). The factors controlling the distribution of rain water upon interaction with plant canopies are numerous and complex, and they vary across species, land use, meteorological conditions, precipitation characteristics (Ávila et al., 2014; Siegert et al., 2016). Moreover, physiological and morphological characteristics related to forest composition and leaf canopy seasonality control rainfall partitioning (Siegert et al., 2016).

The aim was to investigate the floristic composition and phytosociological structure in an anthropized Caatinga area in the State of Pernambuco, Brazil, and to identify which structural variables affect the rainfall partitioning. This information expands the database on anthropized Caatinga fragments.

\section{MATERIAL AND METHODS}

\subsection{Study area}

The study was conducted in the municipality of Floresta

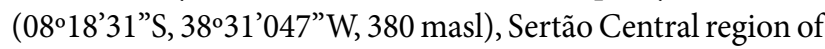
Brazil, in the State of Pernambuco (Figure 1). The climate of the region is a semiarid BSwh' type, according to the Köppen classification (Alvares et al., 2013). The annual rainfall is approximately $489 \mathrm{~mm}$, average temperature of $26^{\circ} \mathrm{C}$, with minimum and maximum of 20.4 and $33.3^{\circ} \mathrm{C}$, in this order and a daily average evapotranspiration equal to $5.5 \mathrm{~mm}$.

The natural vegetation in this region is described as Shrub Savanna-steppe (Caatinga) (Melo et al., 2019) with a height between 3 and $15 \mathrm{~m}$, and which during the wet period exhibit native tree-like shrub and herbaceous stratum species, while in the dry period show Leafless tree-like shrub species and bare soil. The experimental site is located in an area which underwent several years of selective wood extraction and which has a highly heterogeneous landscape characterized by tree-shrub vegetation, with deciduous species. Extensive livestock activities are also performed in the region, with grazing cattle, goat and sheep.

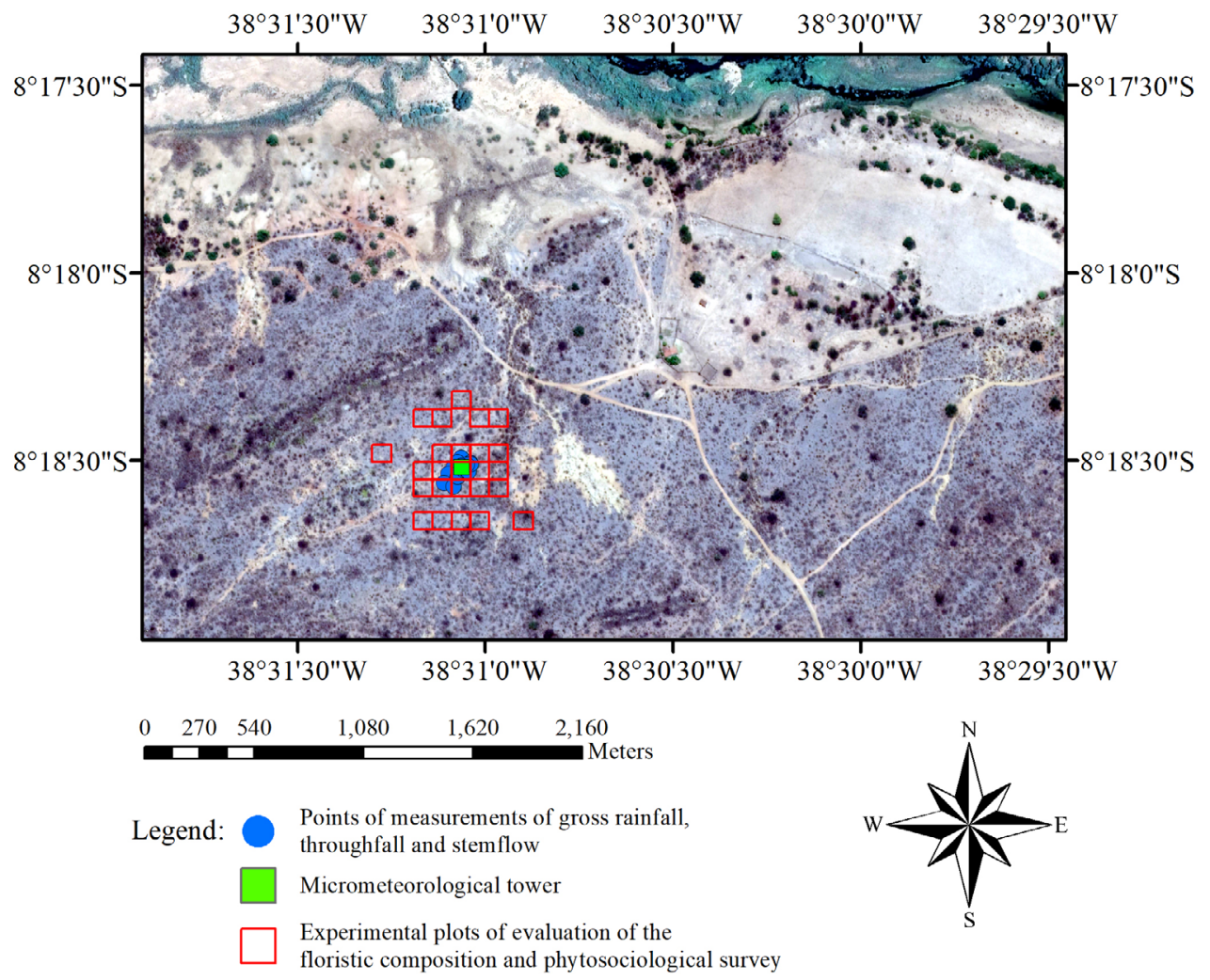

Figure 1. Location map of the study site in the District of Floresta, PE, in the central hinterlands of Brazil. 


\subsection{Floristic composition and phytosociological survey}

Twenty-five $20 \times 20 \mathrm{~m}\left(400 \mathrm{~m}^{2}\right)$ experimental plots were selected and sampled with at least $0.50 \mathrm{~m}$ border (roads, trails, rocky outcrops, etc.). All live shrub-tree individuals (except species of the cactus family) with a circumference at breast height $\left(\mathrm{CBH}_{(\mathrm{i})}\right)$, at $1.3 \mathrm{~m}$ above the soil $\geq 0.6 \mathrm{~m}$ were counted and identified. All species were classified according to the Angiosperm Phylogeny Group (2016) system.

The $\mathrm{CBH}_{(\mathrm{i})}$ and circumference at $0.3 \mathrm{~m} \mathrm{CBL}_{(\mathrm{i})}$ were converted to diameter at breast height $\left(\mathrm{DBH}_{(\mathrm{i})}\right)$ and diameter at soil level $\left(\mathrm{DBL}_{(\mathrm{i})}\right)$. Next, were then calculated individual basal area $\left(\mathrm{BA}_{(\mathrm{i})}\right)$, individual crown area $\left(\mathrm{CA}_{(\mathrm{i})}\right)$, basal area per unit area $\left(\mathrm{BAA}_{(\mathrm{i})}\right)$ and relative basal area $\left(\mathrm{BAr}_{(\mathrm{i})}\right)$, assuming circular shape (Albuquerque et al., 2015). Estimates of biomass (BM(i)) were obtained by allometric equations, as proposed by Sampaio and Silva (2005).

The following variables were calculated for the species: Absolute frequency $\left(\mathrm{Fa}_{(\mathrm{i})}, \%\right)$, relative frequency $\left(\mathrm{Fr}_{(\mathrm{i})}, \%\right)$, absolute density $\left(\mathrm{Da}_{(\mathrm{i})}, \%\right)$, relative density $\left(\operatorname{Dr}_{(\mathrm{i})}, \%\right)$, abundance $\left(\mathrm{A}_{(\mathrm{i})}\right)$, relative abundance $\left(\mathrm{Ar}_{(\mathrm{i})}\right)$, importance value index $\left(\operatorname{IVI}_{(\mathrm{i})}\right)$, relative importance value index $\left(\operatorname{IVIr}_{(\mathrm{i})}\right)$, absolute dominance $\left(\mathrm{DOa}_{(\mathrm{i})}\right)$ and relative dominance $\left(\operatorname{DOr}_{(\mathrm{i})}\right)$, based on the dry biomass of the individuals (Rodal et al., 2008a).

Additionally, were obtained: number of species in the vegetation (v), number of individuals, total density (individuals $\left.\mathrm{ha}^{-1}\right)$, average height $\left(\mathrm{H}_{(\mathrm{v})}, \mathrm{m}\right)$, average total basal area $\left(\mathrm{TBA}_{(\mathrm{v})}\right.$, $\left.\mathrm{cm}^{2} \mathrm{ha}^{-1}\right)$, average crown area $\left(\mathrm{CA}_{(\mathrm{v})}, \mathrm{m}^{2}\right)$, dry biomass per area unit $\left(\mathrm{BM}_{(\mathrm{v})}, \mathrm{kg} \mathrm{ha}^{-1}\right)$. Heterogeneity and floristic diversity were quantified using diversity index (Shannon index, H', nats species ${ }^{-1}$ ) and Pielou evenness index (EH') (Júnior Pereira et al., 2014).

\subsection{Seasonality of Plant Area Index}

The vegetation cover seasonality was assessed based on the estimated Plant Area Index (PAI). For this, photosynthetically active radiation (PAR) was measured using a ceptometer (LP-80, Decagon Devices Inc., Pulman, USA). One reading of incident PAR (open areas) and four readings of PAR transmitted (below the vegetative canopy) were obtained from each of the 27 monitored individuals, totaling 135 readings for each date of measurement, for 14 different dates, from March 2016 to September 2017.

Uninterrupted measurements of PAR were also taken using linear quantum sensors (LI-190SB Quantum sensor, Li-cor, Nebraska, USA) installed above and below the canopy of plants. After the ceptometer and quantum sensor readings were obtained, the intercepted fraction of PAR was calculated according to Equation 1:

$$
f \mathrm{PAR}_{\mathrm{I}}=1-\mathrm{PAR}_{\text {Ibelow }} / \mathrm{PAR}_{\text {Iabove }}
$$

The $f \mathrm{PAR}_{\mathrm{I}(\text { ceptometer) }}$ data were correlated to the corresponding values of $f \mathrm{PAR}_{\mathrm{I}(\text { plants) }}$, resulting in linear equations:

$$
f \mathrm{PAR}_{\mathrm{I}(\mathrm{i})}=\mathrm{a} . f \mathrm{PAR}_{\mathrm{I}(\mathrm{plants})}+\mathrm{b}
$$

where "a" and "b" are coefficients of the equation which varied according to species. This method made it possible to estimate the daily $f \mathrm{PAR}_{\mathrm{I}(\mathrm{i})}$ and thus determine the PAI per species throughout the period from October 2014 to October 2017.

\subsection{Measurements of gross rainfall, throughfall and stemflow}

In the period from March 2016 to September 2017, four processes involved in rainfall partitioning in the Caatinga domain were monitored, namely, gross rainfall (GR), throughfall (TF), stemflow (SF) and interception loss (I).

The GR corresponds to the water volume precipitated before interaction with the plant, and was obtained using a rain gauge (CS700-L, Hydrological Services, Liverpool, Australia) installed at a height of $8 \mathrm{~m}$, at the top of a micrometeorological tower, connected to the datalogger. TF was measured by rain gauges made of PVC with a capture area of $707 \mathrm{~cm}^{2}$ which were positioned randomly at a height of $1.0 \mathrm{~m}$ above the soil surface, beneath the canopy. The gauges were positioned in different places periodically (Vernimmen et al., 2007). Stemflow was collected by zinc structures adapted to plant trees with a circumference greater than $20 \mathrm{~cm}$ at breast height, due to better adherence (Figure 2).

TF and SF were measured in five predominant species: Spondias tuberosa, Commiphora leptophloeos, Cnidoscolus quercifolius, Aspidosperma pyrifolium and Cenostigma pyramidale (three replicates per species).

Collections consisted of one or more events, depending on the possibility of displacement to the experimental area. 


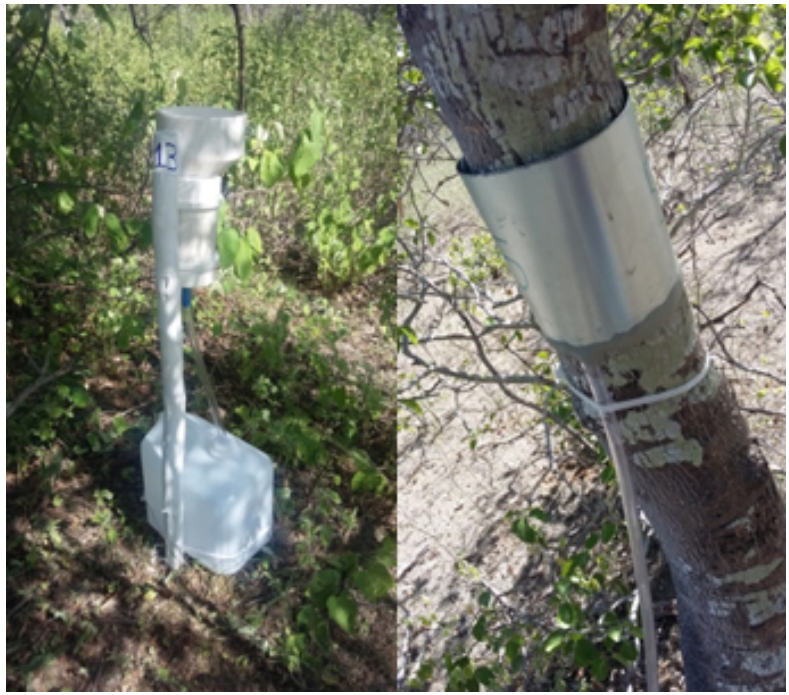

Figure 2. Measurement of throughfall (left) and stemflow (right) in plant species of the Caatinga domain in municipality of Floresta, State of Pernambuco, Brazil.

The volume was converted to SF by dividing it by the canopy projection area (Zabret et al., 2018). Interception loss (in $\mathrm{mm}$ ) is expressed as the GR that does not reach the soil and is retained in the canopy (Equation 3) (Zhang et al., 2015, 2016):

$$
\mathrm{I}=\mathrm{GR}-\mathrm{TF}-\mathrm{SF}
$$

Thus, individual rainfall was accounted for 32 rain events. The accumulated values of rain partition components for five Caatinga plant species (each species contained three replicas) are presented in Table 1.

Table 1. Accumulated values ( $\mathrm{mm}$ ) for throughfall, stemflow and interception loss of five plant species and of the Caatinga domain in the municipality of Floresta, State of Pernambuco, Brazil, from March 2016 to September $2017(n=32)$.

\begin{tabular}{lccc}
\multicolumn{1}{c}{ Species } & Throughfall & Stemflow & Interception loss \\
\hline S. tuberosa & $351.85 \pm 10.18$ & $4.05 \pm 0.05$ & $150.31 \pm 3.28$ \\
C. leptophloeos & $444.31 \pm 11.76$ & $4.05 \pm 0.05$ & $59.88 \pm 3.13$ \\
A. pyrifolium & $412.58 \pm 11.68$ & $6.01 \pm 0.25$ & $89.15 \pm 3.17$ \\
C. quercifolius & $433.53 \pm 12.63$ & $3.29 \pm 0.10$ & $70.59 \pm 4.18$ \\
C. pyramidale & $413.65 \pm 11.12$ & $2.65 \pm 0.14$ & $90.14 \pm 3.10$
\end{tabular}

The same measurements performed in the forest inventory $\left(\mathrm{DBH}_{(\mathrm{i})}, \mathrm{H}_{(\mathrm{i})}, \mathrm{CA}_{(\mathrm{i})}\right.$ and $\left.\mathrm{BM}_{(\mathrm{i})}\right)$ were performed in the trees selected for hydrological measurement. Additionally, the number of shafts was counted and the PAI was estimated per individual. These were the data used in the following step: multivariate analyzes.

\subsection{Statistical analyses}

The following multivariate analyses were employed for the association between structural characteristics of the vegetation $\left(\mathrm{CA}_{(\mathrm{i})}, \mathrm{PAI}_{(\mathrm{i})}, \mathrm{DBH}_{(\mathrm{i})}, \mathrm{SHF}_{(\mathrm{i})}, \mathrm{H}_{(\mathrm{i})}\right.$ and $\left.\mathrm{BM}_{(\mathrm{i})}\right)$, representing the explanatory group and, hydrological variables (TF, ST and I), considered as the response group: Pearson's matrix, multicollinearity, canonical analysis and path analysis, as described in detail in Queiroz et al. (2019). For that, the average values of the structural characteristics of the species and the cumulative values of the hydrological variables obtained for the same species were used. To obtain the averages of the species, we used data from the 27 monitored individuals, representing the five studied species. The analyses were performed in "GENES" software (Cruz, 2006) and the graphs were designed using SigmaPlot 14 software (Systat Software Inc.).

\section{RESULTS AND DISCUSSION}

\subsection{Floristic composition and phytosociological survey}

The total 930 individuals per hectare of 10 shrub-tree species were sampled and grouped into six botanical families, namely, Fabaceae, Apocynaceae, Euphorbiaceae, Anacardiacea, Burseraceae and Bignoniaceae. The first three families contained 415, 280 and 200 individuals, respectively, and can be considered the most abundant ones. Euphorbiaceae was the most species-rich, including three out of the 10 identified species (Table 2).

The sizes of the experimental plots used in phytosociological surveys mostly have dimensions varying between 100 $\mathrm{m}^{2}$ and $400 \mathrm{~m}^{2}$; smaller plots induce the need for more repetitions (Ferraz et al., 2013; Martins et al., 2017; Melo et al., 2019; Rodal et al., 2008a, 2008b). Ferraz et al. (2013) found that the minimum number of sampling plots (plots with $400 \mathrm{~m}^{2}$ ), which result in errors lower than $20 \%$, is 22 units. Thus, the present results, with 25 plots, are representative of the area.

Phytosociological surveys conducted in several Caatinga environments showed that the families Fabaceae, Anacardicaceae and Euphorbiaceae are the most species-rich (Ferraz et al., 2013; Sabino et al., 2016). This fact was confirmed in the present study, where, despite presenting only one species, Fabaceae was the family with the highest number of individuals, whereas the families Anacardicaceae and Euphorbiaceae stood out most (three species each).

Melo et al. (2019) found in an area of Caatinga in the municipality of Floresta that the Fabaceae family had the largest number of individuals, and may be considered great 
richness in studies conducted in seasonally dry tropical forests, due to their adaptation to severe periods of drought. In the Caatinga, deciduous trees to remain with leaves in periods of lower soil moisture, such as C. pyramidale (Fabaceae) and A. pyrifolium (Apocynaceae) (Queiroz et al., 2019). These species are abundant in degraded areas after cutting or burning the Caatinga, and are considered abundant in environments affected by desertification (Souza et al., 2015). Sabino et al. (2016) found in two fragments of an area of anthropized Caatinga (open tree shrub caatinga) that the Fabaceae and Euphorbiaceae families were the richest in species, concentrating $55.7 \%$ and $23.8 \%$ of the total sampled individuals.

Three species stood out with the highest number of representatives, which contributed to a higher relative abundance $\left(\mathrm{Ar}_{(\mathrm{i})}\right)$, namely, C. pyramidale (38\%), A. pyrifolium (26\%) and J. molissima (14\%). Also, along with C. blanchetianus, these species exhibit shrub-like physiognomies, showing lower $\mathrm{H}_{(\mathrm{i})}, \mathrm{DBL}_{(\mathrm{i})}$ and $\mathrm{ABi}_{(\mathrm{i})}$ but accounting for $79 \%$ of the $\operatorname{IVIr}_{(\mathrm{i})}($ Table 2). Dominant taxa were observed, with $88 \%$ of the identified individuals belonging to only three species. Data analysis pointed C. pyramidale as the species holding higher $\mathrm{IVI}_{(\mathrm{i})}$, among the studied. Species like C. pyramidale and $A$. pyrifolium are ecologically dominant and pioneer. Resistance to drought, low-quality wood for coal production and low palatability for domestic animals protect these species against anthropic action (Ferraz et al., 2014; Pereira et al., 2003; Souza et al., 2015), except in the dry periods, when the senescent leaves are a food source for herd (Parente et al., 2012; Souza et al., 2015). Rodal et al. (2008b) mentioned that C. pyramidale is at the top of the Caatinga domain species, whereas A. pyrifolium is structurally relevant in drier Caatinga environments. The higher IVI $_{(\mathrm{i})}$ shows that $C$. pyramidale was more successful in using the resources of the area, indicating its high competitiveness in anthropized environments.

The $\mathrm{H}^{\prime}$ and $\mathrm{EH}^{\prime}$ values were 2.13 nats species ${ }^{-1}$ and 0.93 , respectively, indicating the alpha diversity of the community (Table 2). The values obtained in the present study were higher than those found by Sabino et al. (2016), which ranged between 1.76 and 1.92 for $\mathrm{H}^{\prime}$ and 0.62 and 0.63 for EH'. H' and $\mathrm{EH}^{\prime}$ indices explain plant community diversity. Thus, the values observed in the present study are close to those obtained in anthropized Caatinga areas, as presented by Sabino et al. (2016). Those authors reported H' values in the range of 2.04 to 2.54 .

Diversity indices are influenced by several factors such as sampling methodology, inclusion level, area size and number of sample plots, so the comparison between areas should be made with caution (Melo et al., 2019). It is important to highlight that the Caatinga areas in northeastern Brazil have varying characteristics between regions. Therefore, studies on the floristic composition, richness and structure of the species in the semiarid region are necessary to characterize these environments.

Table 2. Phytosociological variables of species and of the shrub-tree community of the Caatinga domain in the municipality of Floresta, State of Pernambuco, Brazil.

\begin{tabular}{|c|c|c|c|c|c|c|c|c|c|c|}
\hline \multirow{2}{*}{ Family/Species } & NI & $\mathrm{CBL}_{(\mathrm{i})}$ & $\mathrm{CBH}_{(\mathrm{i})}$ & DBL $_{(\mathrm{i})}$ & $\mathbf{D B H}_{(\mathrm{i})}$ & $\mathbf{H}_{(\mathrm{i})}$ & $\mathbf{B A}_{(\mathrm{i})}$ & $\mathrm{CA}_{(\mathrm{i})}$ & $\mathbf{B A A}_{(\mathbf{i})}$ & $\mathbf{B A}_{(\mathrm{i})}$ \\
\hline & Units & $\mathrm{cm}$ & $\mathrm{cm}$ & $\mathbf{m m}$ & $\mathbf{m m}$ & $\mathbf{m}$ & $\mathrm{cm}^{2}$ & $\mathbf{m}^{2}$ & $\mathrm{~m}^{2} \mathbf{h} \mathbf{a}^{-1}$ & - \\
\hline $\begin{array}{l}\text { Fabaceae/Cenostigma pyramidale } \\
\text { (Tul.) Gagnon \& Lewis }\end{array}$ & 415 & $23 \pm 12$ & $17 \pm 12$ & $7 \pm 4$ & $5 \pm 4$ & $4 \pm 1$ & $52 \pm 63$ & $4 \pm 1$ & 3 & 0.31 \\
\hline $\begin{array}{l}\text { Apocynaceae/Aspidosperma } \\
\text { pyrifolium Mart. }\end{array}$ & 280 & $20 \pm 8$ & $14 \pm 7$ & $6 \pm 3$ & $5 \pm 2$ & $3 \pm 1$ & $37 \pm 38$ & $3 \pm 2$ & 2 & 0.19 \\
\hline $\begin{array}{l}\text { Euphorbiaceae /Jatropha } \\
\text { mollissima (Pohl) Baill. }\end{array}$ & 90 & $16 \pm 4$ & $11 \pm 3$ & $5 \pm 1$ & $3 \pm 1$ & $3 \pm 1$ & $21 \pm 12$ & $1 \pm 1$ & 0 & 0.02 \\
\hline $\begin{array}{l}\text { Euphorbiaceae / Croton } \\
\text { blanchetianus Baill. }\end{array}$ & 75 & $9 \pm 2$ & $8 \pm 1$ & $3 \pm 1$ & $3 \pm 0$ & $3 \pm 1$ & $7 \pm 3$ & $1 \pm 0$ & 0 & 0.01 \\
\hline $\begin{array}{l}\text { Euphorbiaceae/Cnidoscolus } \\
\text { quercifolius Pohl }\end{array}$ & 35 & $51 \pm 21$ & $30 \pm 16$ & $16 \pm 7$ & $10 \pm 5$ & $5 \pm 2$ & $239 \pm 167$ & $9 \pm 10$ & 1 & 0.10 \\
\hline $\begin{array}{l}\text { Anacardiaceae/Spondias } \\
\text { tuberosa Arruda }\end{array}$ & 10 & $79 \pm 23$ & $59 \pm 19$ & $25 \pm 7$ & $19 \pm 6$ & $4 \pm 0$ & $506 \pm 243$ & $22 \pm 12$ & 1 & 0.06 \\
\hline $\begin{array}{l}\text { Burseraceae/Commiphora } \\
\text { leptophloeos (Mart.) Gillett }\end{array}$ & 10 & $113 \pm 31$ & $109 \pm 42$ & $36 \pm 10$ & $35 \pm 13$ & $6 \pm 1$ & $1058 \pm 555$ & $65 \pm 40$ & 1 & 0.13 \\
\hline $\begin{array}{l}\text { Anacardiaceae/Myracrodruon } \\
\text { urundeuva Allemão }\end{array}$ & 5 & $47 \pm 5$ & $42 \pm 4$ & $15 \pm 2$ & $13 \pm 1$ & $7 \pm 1$ & $177 \pm 18$ & $13 \pm 1$ & 0 & 0.01 \\
\hline $\begin{array}{l}\text { Bignoniaceae / Tabebuia } \\
\text { aurea (Silva Manso) } \\
\text { Benth. \& Hook.f. ex S.Moore }\end{array}$ & 5 & $86 \pm 9$ & $71 \pm 7$ & $27 \pm 3$ & $22 \pm 2$ & $10 \pm 1$ & $589 \pm 59$ & $31 \pm 3$ & 0 & 0.04 \\
\hline
\end{tabular}


Table 2. Continued...

\begin{tabular}{|c|c|c|c|c|c|c|c|c|c|c|}
\hline \multirow{2}{*}{ Family/Species } & NI & $\mathrm{CBL}_{(\mathrm{i})}$ & $\mathrm{CBH}_{(\mathrm{i})}$ & DBL $_{(i)}$ & DBH $_{(\mathrm{i})}$ & $\mathbf{H}_{(\mathrm{i})}$ & $\mathbf{B A}_{(\mathrm{i})}$ & $\mathrm{CA}_{(\mathrm{i})}$ & $\mathbf{B A A}_{(\mathrm{i})}$ & $\mathbf{B A}_{(\mathbf{i})}$ \\
\hline & Units & $\mathrm{cm}$ & $\mathrm{cm}$ & $\mathbf{m m}$ & $\mathbf{m m}$ & m & $\mathrm{cm}^{2}$ & $\mathbf{m}^{2}$ & $\mathrm{~m}^{2} \mathbf{h a}^{-1}$ & - \\
\hline $\begin{array}{l}\text { Anacardiaceae/Schinopsis } \\
\text { brasiliensis Engl. }\end{array}$ & 5 & $164 \pm 16$ & $143 \pm 14$ & $52 \pm 5$ & $45 \pm 5$ & $15 \pm 2$ & $2140 \pm 214$ & $98 \pm 10$ & 1 & 0.13 \\
\hline$\Sigma$ & 930 & - & - & - & - & - & - & - & 8 & 1.00 \\
\hline$\mu$ & 38 & $61 \pm 13$ & $50 \pm 13$ & $19 \pm 4$ & $16 \pm 4$ & $6 \pm 1$ & $482 \pm 137$ & $25 \pm 8$ & 1 & 0.10 \\
\hline \multirow{2}{*}{ Family/Species } & $\mathbf{F a} \mathbf{a}_{(\mathrm{i})}$ & $\mathrm{Fr}_{(\mathrm{i})}$ & $\mathbf{D} \mathbf{a}_{(\mathrm{i})}$ & $\mathbf{D r} \mathbf{r}_{(i)}$ & $\mathbf{A}_{(\mathbf{i})}$ & $A \mathbf{r}_{(i)}$ & $\mathbf{I V I}_{(\mathrm{i})}$ & $\operatorname{IVIr}_{(\mathrm{i})}$ & $\mathbf{D O a}_{(\mathrm{i})}$ & $\mathrm{DOr}_{(\mathrm{i})}$ \\
\hline & & & Ind. $h^{-1}$ & - & - & - & - & $\%$ & \multicolumn{2}{|l|}{$t h a^{-1}$} \\
\hline $\begin{array}{l}\text { Fabaceae/Cenostigma pyramidale } \\
\text { (Tul.) Gagnon \& Lewis }\end{array}$ & 1.0 & 0.17 & 415 & 0.45 & 17 & 0.38 & 1.00 & 0.33 & 1522 & 0.45 \\
\hline $\begin{array}{l}\text { Apocynaceae/Aspidosperma } \\
\text { pyrifolium Mart. }\end{array}$ & 1.0 & 0.17 & 280 & 0.30 & 11 & 0.26 & 0.73 & 0.24 & 969 & 0.29 \\
\hline $\begin{array}{l}\text { Euphorbiaceae /Jatropha } \\
\text { mollissima (Pohl) Baill. }\end{array}$ & 0.6 & 0.10 & 90 & 0.10 & 6 & 0.14 & 0.34 & 0.11 & 223 & 0.07 \\
\hline $\begin{array}{l}\text { Euphorbiaceae /Croton } \\
\text { blanchetianus Baill. }\end{array}$ & 1.0 & 0.17 & 75 & 0.08 & 3 & 0.07 & 0.32 & 0.11 & 244 & 0.07 \\
\hline $\begin{array}{l}\text { Euphorbiaceae/Cnidoscolus } \\
\text { quercifolius Pohl }\end{array}$ & 0.8 & 0.14 & 35 & 0.04 & 2 & 0.04 & 0.22 & 0.07 & 120 & 0.04 \\
\hline $\begin{array}{l}\text { Anacardiaceae/Spondias } \\
\text { tuberosa Arruda }\end{array}$ & 0.4 & 0.07 & 10 & 0.01 & 1 & 0.02 & 0.10 & 0.03 & 62 & 0.02 \\
\hline $\begin{array}{l}\text { Burseraceae/Commiphora } \\
\text { leptophloeos (Mart.) Gillett }\end{array}$ & 0.4 & 0.07 & 10 & 0.01 & 1 & 0.02 & 0.10 & 0.03 & 104 & 0.03 \\
\hline $\begin{array}{l}\text { Anacardiaceae/Myracrodruon } \\
\text { urundeuva Allemão }\end{array}$ & 0.2 & 0.03 & 5 & 0.01 & 1 & 0.02 & 0.06 & 0.02 & 14 & 0.00 \\
\hline $\begin{array}{l}\text { Bignoniaceae / Tabebuia } \\
\text { aurea (Silva Manso) } \\
\text { Benth. \& Hook.f. ex S.Moore }\end{array}$ & 0.2 & 0.03 & 5 & 0.01 & 1 & 0.02 & 0.06 & 0.02 & 37 & 0.01 \\
\hline $\begin{array}{l}\text { Anacardiaceae/Schinopsis } \\
\text { brasiliensis Engl. }\end{array}$ & 0.2 & 0.03 & 5 & 0.01 & 1 & 0.02 & 0.06 & 0.02 & 79 & 0.02 \\
\hline$\Sigma$ & 5.8 & 1.00 & 930 & 1.00 & 44 & 1.00 & 3.00 & 1.00 & 3375 & 1.00 \\
\hline$\mu$ & 0.6 & 0.10 & 93 & 0.10 & 4 & 0.10 & 0.30 & 0.10 & 338 & 0.10 \\
\hline \multicolumn{11}{|c|}{ Caatinga } \\
\hline TDV & CBLv & $\mathrm{CBHv}$ & DBLv & $\mathrm{DBHv}$ & $\mathrm{Hv}$ & $\mathrm{BAv}$ & CAv & $\mathrm{BMv}$ & $\mathrm{H}^{\prime}$ & EH' \\
\hline Ind. ha ${ }^{-1}$ & $\mathrm{~mm}$ & $\mathrm{~mm}$ & $\mathrm{~mm}$ & $\mathrm{~mm}$ & $\mathrm{~m}$ & $\mathrm{~m}^{2} \mathrm{ha}^{-1}$ & $\mathrm{~m}^{2}$ & $\mathrm{~kg} \mathrm{ha}^{-1}$ & nats $\mathrm{spc}^{-1}$ & - \\
\hline 930 & $25 \pm 23$ & $18 \pm 17$ & $7.81 \pm 7.40$ & $6 \pm 6$ & $3.56 \pm 1.87$ & 0.04 & $4.72 \pm 14.53$ & $3375 \pm 88$ & 2.13 & 0.93 \\
\hline
\end{tabular}

NI - number of individuals, $\mathrm{CBL}_{(i)}$ - circumference at basal level, $\mathrm{CBH}_{(\mathrm{i})}$ - circumference at the height of $1.3 \mathrm{~m}, \mathrm{DBL}_{(\mathrm{i})}$ - diameter at basal level, $\mathrm{DBH}_{(\mathrm{i})}$ - diameter at the height of $1.3 \mathrm{~m}, \mathrm{H}_{(\mathrm{i})}$ - plant height, $\mathrm{BA}_{(\mathrm{i})}$ - individual basal area, $\mathrm{CA}_{(\mathrm{i})}$ - crown area, $\mathrm{BAA}_{(\mathrm{i})}$ - basal area per unit area, $\mathrm{BAAr}_{(\mathrm{i})}-$ relative basal area, $\mathrm{Fa}_{(\mathrm{i})}-$ absolute frequency, $\mathrm{Fr}_{(i)}$ - relative frequency, $\mathrm{Da}$ - absolute density, $\mathrm{Dr}_{\text {- }}$ - relative density, $\mathrm{A}$ - abundance, $\mathrm{Ar}_{(i)}$ - relative abundance, IVI - importance value index, IVIr relative importance value index, $\mathrm{DOa}_{(\mathrm{i})}$ - absolute dominance, $\mathrm{DOr}_{(\mathrm{i})}=$ relative dominance, TDV - total density of the vegetation, CBLv - average circumference of the vegetation at basal level, $\mathrm{CBHv}$ - average circumference of the vegetation at the height of $1.3 \mathrm{~m}$, DBLv - average diameter of the vegetation at basal level, DBHv average diameter of the vegetation at the height of $1.30 \mathrm{~m}, \mathrm{Hv}$ - average height of the vegetation, BAv - average basal area of the vegetation, CAv - crown area of the vegetation, $\mathrm{BMv}$ - biomass of the vegetation, $\mathrm{H}^{\prime}$ - Shannon index, $\mathrm{EH}$ - Pielou index. Ind. - individual, spc. - species.

\subsection{Seasonality of Plant Area Index}

The PAI varied largely between the species, with higher values in S. tuberosa, followed by C. leptophloeos and C. quercifolius (Figure 3). The other species exhibited a low and similar PAI, all of which were characterized as shrubs. Cenostigma pyramidale was the species with the highest PAI. The PAI data varied in accordance with the monthly seasonality of precipitation, with a slight delay in response, especially in the rainy period of 2016. On average, the PAI values for the six monitored species, in decreasing order, were $2.11 \mathrm{~m}^{2} \mathrm{~m}^{-2}$ for S. tuberosa, $1.95 \mathrm{~m}^{2} \mathrm{~m}^{-2}$ for C. leptophloeos, $1.73 \mathrm{~m}^{2} \mathrm{~m}^{-2}$ for C. quercifolius, $1.34 \mathrm{~m}^{2} \mathrm{~m}^{-2}$ for A. pyrifolium, $1.10 \mathrm{~m}^{2} \mathrm{~m}^{-2}$ for C. blanchetianus and $0.94 \mathrm{~m}^{2} \mathrm{~m}^{-2}$ for C. pyramidale (Figure 3). 


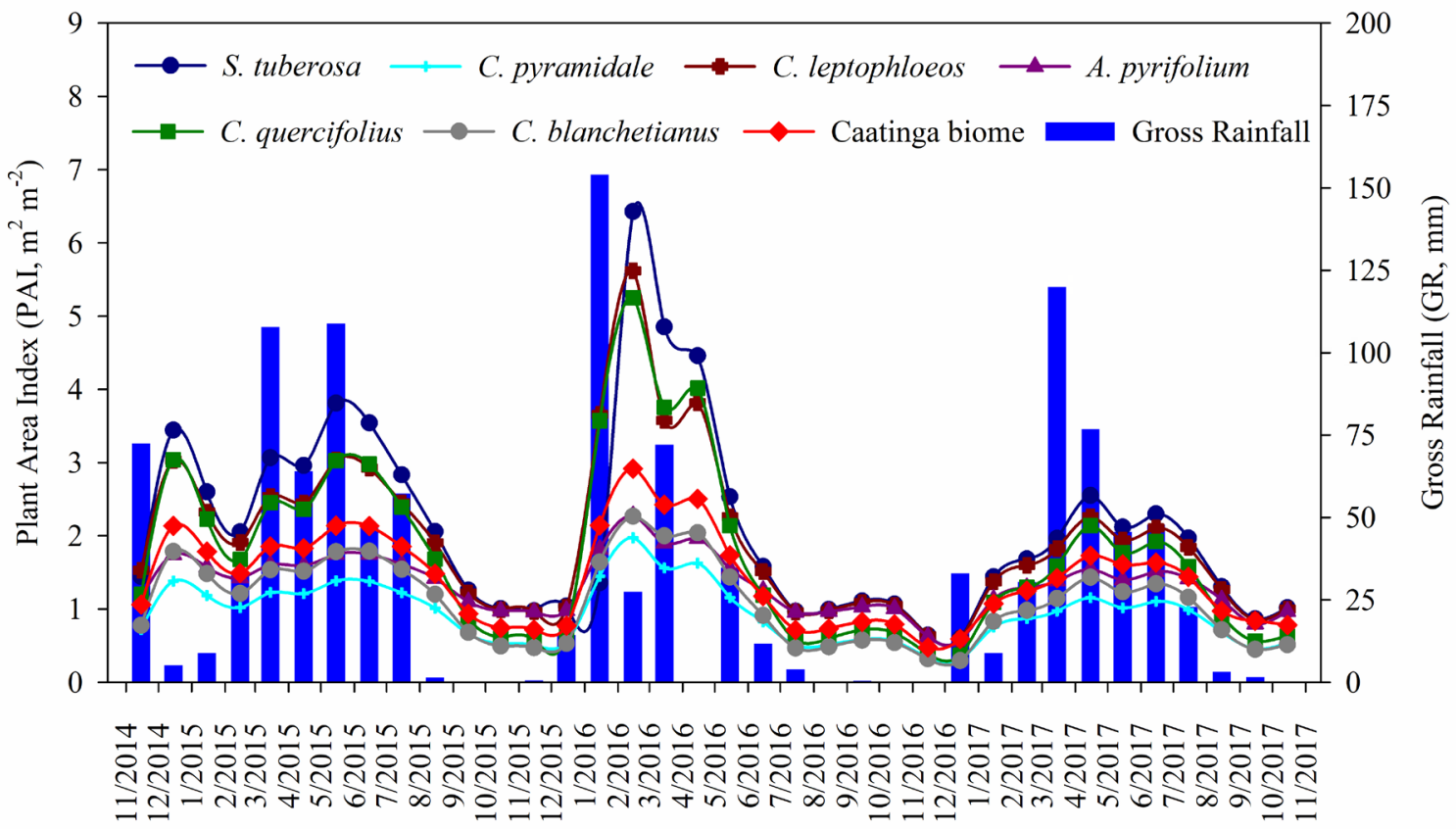

Date (Month/Year)

Figure 3. Seasonality of plant area index of six plant species and of the Caatinga domain in the municipality of Floresta, State of Pernambuco, Brazil, from October 2014 to October 2017.

The species that exhibited the highest PAI values (S. tuberosa, C. leptophloeos and C. quercifolius) are characterized by having higher $\mathrm{H}_{(\mathrm{i})}, \mathrm{DBH}_{(\mathrm{i})}, \mathrm{CA}_{(\mathrm{i})}$ and $\mathrm{BM}_{(\mathrm{i})}$, favoring the formation of canopy (leaves and branches). For the shrub species ( $A$. pyrifolium, C. blanchetianus and C. pyramidale), the occurrence of low $\mathrm{DBH}_{(\mathrm{i})}$ values $(<10 \mathrm{~cm})$ coupled with lower $\mathrm{H}_{(\mathrm{i})}$ and $\mathrm{CA}_{(\mathrm{i})}$ is responsible for the lower PAI. Those attributes confirm the structural mosaic of the Caatinga (Rodal et al., 2008a; Beuchle et al., 2015). The variation in PAI showed that the water regime is a key factor in the formation of the vegetative canopy of species, especially due to the deciduousness in response to water deficit. Pinto-Júnior et al. (2011) stated that this phenomenon is typical of domains subjected to fluctuations in precipitation, even in rainforests.

\subsection{Association between structural characteristics and hydrological variables of the vegetation}

The response hydrological variables (TF, SF and I) exhibited a correlation with the following explanatory variables: $\mathrm{CA}_{(\mathrm{i})}$, $\mathrm{PAI}_{(\mathrm{i})}, \mathrm{DBH}_{(\mathrm{i})}$, number of shafts $\left(\mathrm{SHF}_{(\mathrm{i})}\right), \mathrm{H}_{(\mathrm{i})}$ and BM $(\mathrm{i})$. After applying multicollinearity analysis and checking for severe multicollinearity, $\mathrm{CA}_{(\mathrm{i})}$ and $\mathrm{PAI}_{(\mathrm{i})}$ were removed from the group of explanatory variables, leaving the $\mathrm{DBH}_{(\mathrm{i})}, \mathrm{SHF}_{(\mathrm{i})}, \mathrm{H}_{(\mathrm{i})}$ and $\mathrm{BM}_{(\mathrm{i})}$ variables for canonical and path analyses. The occurrence of severe multicollinearity indicates the independent variables that should be removed from the analysis, as they are much correlated. Canonical analysis indicated that there was no association between the two groups, since the canonical axes were not significant according to the chi-squared test $(\mathrm{p}>0.05)$. The decomposition of the correlation coefficients in path analysis (Table 3 ) revealed a direct negative effect of $\mathrm{DBH}_{(\mathrm{i})}(-1.50)$ and a direct and positive effect of $\mathrm{BM}_{(\mathrm{i})}(1.78)$ on the hydrological variable of IP. For SF, there were a direct negative effect of $\mathrm{BM}_{(\mathrm{i})}(-0.46)$ and an indirect negative effect of $\mathrm{DBH}_{(\mathrm{i})}(-0.44)$. Lastly, for $\mathrm{I}, \mathrm{BM}_{(\mathrm{i})}$ showed direct $(-1.78)$ and indirect $(-1.70)$ negative effects via $\mathrm{DBH}_{(\mathrm{i})}$, whereas $\mathrm{DBH}_{(\mathrm{i})}$ had a negative indirect effect via SHF $(-0.45)$ and a positive indirect effect via $\mathrm{H}_{(\mathrm{i})}(1.44)$. However, a high residual error $(>0.80)$ was observed in this analysis (greater than the termination coefficient, $<0.35$ ), indicating that other factors influence the partition of the rainfall in the Caatinga more than the structural characteristics of the vegetation species (e.g. meteorological variables, rainfall intensity, leaf angle, leaf hydrophobicity, and water droplet retention) (Limin et al., 2015; Zhang et al., 2015; Zhang et al., 2016).

In this study, the increase in $\mathrm{DBH}_{(\mathrm{i})}$ is in line with the $\mathrm{BM}_{(\mathrm{i})}$ data. Commiphora leptophloeos has higher $\mathrm{DBH}_{(\mathrm{i})}$ and $\mathrm{BM}_{(\mathrm{i})}$ values, but its hydrological measurements are similar to those of other species, except for S. tuberosa (Table 1). 
Table 3. Decomposition of Pearson's correlation coefficient into direct and indirect effects of the response hydrological variables (throughfall, stemflow and interception loss) on the explanatory structural variables $\left(\mathrm{DBH}_{(\mathrm{i})}\right.$ - diameter at the height of $1.3 \mathrm{~m}$; $\mathrm{SHF}_{(\mathrm{i})}$ - number of shafts; $\mathrm{H}_{(\mathrm{i})}$ - plant height; and $\mathrm{BM}_{(\mathrm{i})}$ - biomass) for Caatinga domain species in the municipality of Floresta, State of Pernambuco, Brazil.

\begin{tabular}{|c|c|c|c|c|c|c|}
\hline \multirow[b]{2}{*}{ Direct effect } & \multicolumn{2}{|c|}{ Throughfall } & \multicolumn{2}{|c|}{ Stemflow } & \multicolumn{2}{|c|}{ Interception loss } \\
\hline & $\mathrm{DBH}_{(\mathrm{i})}$ & -1.50 & $\mathrm{DBH}_{(\mathrm{i})}$ & 0.01 & $\mathrm{DBH}_{(\mathrm{i})}$ & 1.52 \\
\hline Indirect effect & $\operatorname{SHF}_{(\mathrm{i})}$ & 0.06 & $\operatorname{SHF}_{(\mathrm{i})}$ & -0.01 & $\mathrm{SHF}_{(\mathrm{i})}$ & -0.06 \\
\hline Indirect effect & $\mathrm{H}_{(\mathrm{i})}$ & 0.05 & $\mathrm{H}_{(\mathrm{i})}$ & -0.05 & $\mathrm{H}_{(\mathrm{i})}$ & -0.05 \\
\hline Indirect effect & $\mathrm{BM}_{(\mathrm{i})}$ & 1.69 & $\mathrm{BM}_{(\mathrm{i})}$ & -0.44 & $\mathrm{BM}_{(\mathrm{i})}$ & -1.70 \\
\hline- & Total $\mathrm{r}$ & 0.30 & Total $\mathrm{r}$ & -0.48 & Total $\mathrm{r}$ & -0.28 \\
\hline Direct effect & $\operatorname{SHF}_{(i)}$ & -0.19 & $\operatorname{SHF}_{(i)}$ & 0.02 & $\operatorname{SHF}_{(\mathrm{i})}$ & 0.19 \\
\hline Indirect effect & $\mathrm{DBH}_{(\mathrm{i})}$ & 0.44 & $\mathrm{DBH}_{(\mathrm{i})}$ & -0.00 & $\mathrm{DBH}_{(\mathrm{i})}$ & -0.45 \\
\hline Indirect effect & $\mathrm{H}_{(\mathrm{i})}$ & -0.03 & $\mathrm{H}_{(\mathrm{i})}$ & 0.02 & $\mathrm{H}_{(\mathrm{i})}$ & 0.03 \\
\hline Indirect effect & $\mathrm{BM}_{(\mathrm{i})}$ & -0.41 & $\mathrm{BM}_{(\mathrm{i})}$ & 0.10 & $\mathrm{BM}_{(\mathrm{i})}$ & 0.40 \\
\hline- & Total $\mathrm{r}$ & -0.19 & Total $\mathrm{r}$ & 0.15 & Total $\mathrm{r}$ & 0.18 \\
\hline Direct effect & $\mathrm{H}_{(\mathrm{i})}$ & 0.15 & $\mathrm{H}_{(\mathrm{i})}$ & -0.12 & $\mathrm{H}_{(\mathrm{i})}$ & -0.14 \\
\hline Indirect effect & $\mathrm{DBH}_{(\mathrm{i})}$ & -0.56 & $\mathrm{DBH}_{(\mathrm{i})}$ & 0.00 & $\mathrm{DBH}_{(\mathrm{i})}$ & 0.57 \\
\hline Indirect effect & $\mathrm{SHF}_{(\mathrm{i})}$ & 0.04 & $\operatorname{SHF}_{(\mathrm{i})}$ & -0.01 & $\mathrm{SHF}_{(\mathrm{i})}$ & -0.04 \\
\hline Indirect effect & $\mathrm{BM}_{(\mathrm{i})}$ & 0.45 & $\mathrm{BM}_{(\mathrm{i})}$ & -0.12 & $\mathrm{BM}_{(\mathrm{i})}$ & -0.45 \\
\hline- & Total $\mathrm{r}$ & 0.08 & Total $\mathrm{r}$ & -0.24 & Total $\mathrm{r}$ & -0.06 \\
\hline Direct effect & $\mathrm{BM}_{(\mathrm{i})}$ & 1.78 & $\mathrm{BM}_{(\mathrm{i})}$ & -0.46 & $\mathrm{BM}_{(\mathrm{i})}$ & -1.78 \\
\hline Indirect effect & $\mathrm{DBH}_{(\mathrm{i})}$ & -1.43 & $\mathrm{DBH}_{(\mathrm{i})}$ & 0.00 & $\mathrm{DBH}_{(\mathrm{i})}$ & 1.44 \\
\hline Indirect effect & $\operatorname{SHF}_{(i)}$ & 0.04 & $\operatorname{SHF}_{(i)}$ & -0.01 & $\mathrm{SHF}_{(\mathrm{i})}$ & -0.04 \\
\hline Indirect effect & $\mathrm{H}_{(\mathrm{i})}$ & 0.04 & $\mathrm{H}_{(\mathrm{i})}$ & -0.03 & $\mathrm{H}_{(\mathrm{i})}$ & -0.04 \\
\hline- & Total $\mathrm{r}$ & 0.43 & Total $\mathrm{r}$ & -0.48 & Total $\mathrm{r}$ & - \\
\hline $\mathrm{r}^{2}$ & - & 0.35 & - & 0.25 & - & 0.35 \\
\hline Residual & - & 0.80 & - & 0.86 & - & 0.80 \\
\hline
\end{tabular}

Jian et al. (2014) found positive correlations between the SF of two shrub species and their structural characteristics (projected area, number of branches, height and crown volume) in an area of the semi-arid region of China (average precipitation $=420 \mathrm{~mm}$ ). In their study, the largest species generated the highest SF. By contrast, Limin et al. (2015) studied a clove plantation in Saba River Basin, Bali, Indonesia, and did not find a significant correlation between TF and canopy opening, with low $\mathrm{r}^{2}$ values.

In this study, C. leptophloeos has, on average, only one shaft and wide crowns; thus, despite its tall size and elevated biomass, TF and SF are facilitated, resulting in a lower I. The results of the multivariate analysis contribute to encourage future work on the influence of other structural characteristics of the species that improve the understanding of their associations with the hydrological variables of the Caatinga. The high residual error in path analysis reinforces the multiplicity of the Caatinga vegetation.

\section{CONCLUSIONS}

For the anthropized Caatinga fragment evaluated was identified that:

- The Fabaceae family presented the highest species richness;

- $\quad$ The Cenostigma pyramidale (Tul.) Gagnon \& Lewis species had the highest abundance, dominance, frequency and importance value index values, being the most important phytosociological species in the community;

- Precipitation characterized the variation of plant area index, with clear differences existing between the tree and shrub species;

- The structural characteristics of the plants considered in this study did not explain the dynamics of hydrological variables (throughfall, stemflow and interception loss) of the Caatinga vegetation. 


\section{SUBMISSION STATUS}

Received: 14 Mar. 2019

Accepted: 19 Jun. 2020

Associate editor: Rafaella Curto

\section{CORRESPONDENCE TO}

\section{Thieres George Freire da Silva}

Universidade Federal Rural de Pernambuco (UFRPE), Avenida Gregório Ferraz Nogueira, S/N, Bairro José Tomé de Souza Ramos, CEP 56.909-535, Serra Talhada, PE, Brasil.

E-mail: thieres_freire@yahoo.com.br

\section{REFERENCES}

Albuquerque, E.R.G.M., Sampaio, E.V.S.B., Pareyn, F.G.C., Araújo, E.L., 2015. Root biomass under stem bases and at different distances from trees. J. Arid Environ. 116, 82-88. https://doi.org/10.1016/j. jaridenv.2015.02.003

Alvares, C.A., Stape, J.L., Sentelhas, P.C., Gonçalves, J.L.M., Sparovek, G., 2013. Köppen's climate classification map for Brazil. Meteorol. Zeitschrift 22, 711-728. https://doi.org/10.1127/09412948/2013/0507

Ávila, L.F., Mello, C.R. de, Pinto, L.C., Silva, A.M. da, 2014. Partição da precipitação pluvial em uma microbacia hidrográfica ocupada por mata atlântica na serra da Mantiqueira, MG. Ciência Florest. 24, 583-595.

Batista, A.P.B., Rodal, M.J.N., José Antonio Aleixo da Silva, Silva, A.C.B.L. e, Alves Junior, F.T., Mello, J.M., 2015. Dynamics and prediction of diametric structure in two Atlantic Forest fragments in northeastern Brazil. Rev. Árvore 40, 307-317. https://doi.org/ http://dx.doi.org/10.1590/0100-67622016000200013

Beuchle, R., Grecchi, R.C., Shimabukuro, Y.E., Seliger, R., Eva, H.D., Sano, E., Achard, F., 2015. Land cover changes in the Brazilian Cerrado and Caatinga biomes from 1990 to 2010 based on a systematic remote sensing sampling approach. Appl. Geogr. 58, 116-127. https://doi.org/10.1016/j.apgeog.2015.01.017

Ferraz, J.S.F., Ferreira, R.L.C., Silva, J.A.A. da, Meunier, I.M.J., Santos, M.V.F. dos, 2014. Estrutura do componente arbustivo-arbóreo da vegetação em duas áreas de caatinga, no município de Floresta, Pernambuco. Rev. Árvore 38, 1055-1064.

Ferraz, R.C., Mello, A.A. de, Ferreira, R.A., Prata, A.P. do N., 2013. Levantamento fitossociológico em área de caatinga no monumento natural grota do angico, Sergipe, Brasil. Rev. Caatinga 26, 89-98.

Ferreira, P.S.M., Lopes, S. de F., Trovão, D.M. de B.M., 2016. Patterns of species richness and abundance among cactus communities receiving different rainfall levels in the semiarid region of Brazil. Acta Bot. Brasilica 30, 569-576. https://doi.org/10.1590/0102-33062016abb0084

Germer, S., Werther, L., Elsenbeer, H., 2010. Have we underestimated stemflow? Lessons from an open tropical rainforest. J. Hydrol. 395, 169-179. https://doi.org/10.1016/j.jhydrol.2010.10.022

Jian, S.Q., Zhao, C.Y., Fang, S.M., Yu, K., 2014. Characteristics of Caragana korshinskii and Hippophae rhamnoides stemflow and their significance in soil moisture enhancement in Loess Plateau, China. J. Arid Land 6, 105-116. https://doi.org/10.1007/s40333-013-0189-4
Júnior Pereira, R.L., Andrade, A.P. de, Araújo, K.D., Barbosa, A. da S., Barbosa, F.M., 2014. Espécies da Caatinga como Alternativa para o Desenvolvimento de Novos Fitofármacos Caatinga Species as an Alternative to the Development of New Phytochemicals. Floresta e Ambient. 21, 509-520. https://doi.org/10.1590/2179-8087.024212

Limin, S.G., Oue, H., Sato, Y., Budiasa, I.W., setiawan, B.I., 2015. Partitioning Rainfall into Throughfall, Stemflow, and Interception Loss in Clove (Syzygium Aromaticum) Plantation in Upstream Saba River Basin, Bali. Procedia Environ. Sci. 28, 280-285. https://doi. org/10.1016/j.proenv.2015.07.036

Martins, P.J., Mazon, J.A., Martinkoski, L., Benin, C.C., Watzlawick, L.F., 2017. Dinâmica da Vegetação Arbórea em Floresta Ombrófila Mista Montana Antropizada. Floresta e Ambient. 24, 1-12. https://doi.org/10.1590/2179-8087.097014

Melo, C.L.S.M.S. de, Ferreira, R.L.C., Silva, J.A.A. da, Machuca, M.Á.H., Cespedes, G.H.G., 2019. Dynamics of dry tropical forest after three decades of vegetation suppression. Floresta e Ambient. 26, 1-12. https://doi.org/10.1590/2179-8087.116317

Parente, H.N., Andrade, A.P. de, Silva, D.S. da, Santos, E.M., Araujo, K.D., Parente, M. de O.M., 2012. Influência do pastejo e da precipitação sobre a fenologia de quatro espécies em área de caatinga. Rev. Árvore 36, 411-421. https://doi.org/10.1590/S0100-67622012000300003

Pereira, I.M., Andrade, L.A., Sampaio, E.V.S.B., Barbosa, M.R. V., 2003. Use-history Effects on Structure and Flora of Caatinga. Biotropica 35, 154-165. https://doi.org/10.1111/j.1744-7429.2003.tb00275.x

Queiroz, M.G. de, Silva, T.G.F. da, Zolnier, S., Souza, C.A.A. de, Souza, L.S.B. de, Steidle Neto, A.J., Araujo, G.G.L. De, Ferreira, W.P.M., 2019. Seasonal patterns of deposition litterfall in a seasonal dry tropical forest. Agric. For. Meteorol. 279, 107712. https://doi.org/10.1016/j.agrformet.2019.107712

Rodal, M.J.N., Costa, K.C.C., Silva, A.C.B.L. e, 2008a. Estrutura da vegetação caducifólia espinhosa (caatinga) de uma área do sertão central de Pernambuco. Hoehnea 35, 209-217. https:// doi.org/10.1590/S2236-89062008000200004

Rodal, M.J.N., Martins, F.R., Sampaio, E.V. de S.B., 2008b. Levantamento quantitativo das plantas lenhosas em trechos de vegetação de caatinga em Pernambuco. Rev. Caatinga 21, 192-205.

Rodrigues, D.R., Bovolenta, Y.R., Pimenta, J.A., Bianchini, E., 2016. Height structure and spatial pattern of five tropical tree species in two seasonal semideciduous forest fragments with different conservation histories. Rev. Árvore 40, 395-405. https://doi.org/ http://dx.doi.org/10.1590/0100-67622016000300003

Sabino, F.G. da S., Cunha, M. do C.L., Santana, G.M., 2016. Estrutura da Vegetação em Dois Fragmentos de Caatinga Antropizada na Paraíba. Floresta e Ambient. 23, 487-497. https:// doi.org/10.1590/2179-8087.017315

Sampaio, E.V.S.B., Silva, G.C., 2005. Biomass equations for Brazilian semiarid caatinga plants. Acta Bot. Brasilica 19, 935-943. https:// doi.org/10.1590/S0102-33062005000400028

Schulz, K., Voigt, K., Beusch, C., Almeida-Cortez, J.S., Kowarik, I., Walz, A., Cierjacks, A., 2016. Grazing deteriorates the soil carbon stocks of Caatinga forest ecosystems in Brazil. For. Ecol. Manage. 367, 62-70. https://doi.org/10.1016/j.foreco.2016.02.011

Siegert, C.M., Levia, D.F., Hudson, S.A., Dowtin, A.L., Zhang, F., Mitchell, M.J., 2016. Small-scale topographic variability influences 
tree species distribution and canopy throughfall partitioning in a temperate deciduous forest. For. Ecol. Manage. 359, 109-117. https://doi.org/10.1016/j.foreco.2015.09.028

Souza, B.I., Menezes, R., Cámara Artigas, R., 2015. Efeitos da desertificação na composição de espécies do bioma Caatinga, Paraíba/ Brasil. Investig. Geogr. 2015, 45-59. https://doi.org/10.14350/rig.44092

Vernimmen, R.R.E., Bruijnzeel, L.A., Romdoni, A., Proctor, J., 2007. Rainfall interception in three contrasting lowland rain forest types in Central Kalimantan, Indonesia. J. Hydrol. 340, 217-232. https:// doi.org/10.1016/j.jhydrol.2007.04.009

Vieira, I.R., de Araújo, F.S., Zandavalli, R.B., 2013. Shrubs promote nucleation in the Brazilian semi-arid region. J. Arid Environ. 92, 42-45. https://doi.org/10.1016/j.jaridenv.2013.01.009
Zabret, K., Joz`e Rakovec, Mojca Šraj, 2018. Influence of meteorological variables on rainfall partitioning for deciduous and coniferous tree species in urban area. J. Hydrol. 558, 29-41. https:// doi.org/https://doi.org/10.1016/j.jhydrol.2018.01.025

Zhang, Y. feng, Wang, X. ping, Hu, R., Pan, Y. xia, Paradeloc, M., 2015. Rainfall partitioning into throughfall, stemflow and interception loss by two xerophytic shrubs within a rain-fed revegetated desert ecosystem, northwestern China. J. Hydrol. 527, 1084-1095. https://doi.org/10.1016/j.jhydrol.2015.05.060

Zhang, Y.F., Wang, X.P., Hu, R., Pan, Y.X., 2016. Throughfall and its spatial variability beneath xerophytic shrub canopies within waterlimited arid desert ecosystems. J. Hydrol. 539, 406-416. https://doi. org/10.1016/j.jhydrol.2016.05.051 